\title{
VERIFICATION AND VALIDATION OF A NUMERICAL MODEL OF FIRE AND SMOKE DEVELOPMENT IN A RAILWAY TUNNEL
}

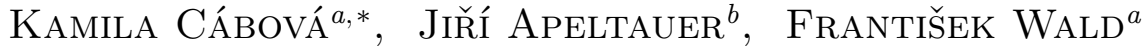 \\ ${ }^{a}$ Department of Steel and Timber Structures, Faculty of Civil Engineering, Czech Technical University in Prague, \\ Prague, Czech Republic \\ ${ }^{b}$ Institute of Road Structures, Brno University of Technology, Brno, Czech Republic \\ * corresponding author: kamila.cabova@fsv.cvut.cz
}

\begin{abstract}
The paper describes the verification and validation of a numerical model of the development of fire and smoke in a railway tunnel carried out in the Fire Dynamic Simulator numerical code. To evaluate the correctness of a numerical solution of the model with respect to the mathematical model, the results are compared with a solution executed in the SmartFire numerical code. The influence of mesh size on the gas temperature results in the vicinity of the fire source is studied. The level of agreement between the numerical model and a physical model is validated by comparing the calculated data with data measured during a fire test in the Valík road tunnel in the Czech Republic.
\end{abstract}

KEYworDs: verification; validation; FDS; Smart Fire; railway tunnel; fire and smoke development; fire test.

\section{INTRODUCTION}

Modelling fires with the use of computational fluid dynamics (CFD) has been a research topic since the introduction of computational techniques in fire science in the 1980s [1. However, it is only in the last decade that computer technology and knowledge of fire dynamics have grown sufficiently for simulations to be carried out in real size enclosures. Nowadays, mathematical modeling of fire dynamics plays an important role in two branches of fire engineering: in the design of fire safety strategies, and in a posteriori modelling of accidental fires [2]. A number of commercial and also freely available software tools that implement the CFD method have been available for some years. The use of this software is complex and time-consuming. Taking the greater resolution of fire behaviour available from CFD models into consideration, great care must be taken when obtaining and interpreting predictions, as the output can be enormously influenced even by minor differences in input data 3. The implications of not having the correct input data have been highlighted in [1]. In [4], it was concluded that at present CFD predictions of fire growth are not sufficiently reliable for use in engineering design, unless they are directly supported by experimental validation. However, the authors also noted that if the use of CFD models is restricted to the prediction of gas temperatures for a given fire heat release rate, good predictions can be made. For tunnel fires, the thermo-fluid-dynamics behaviour is affected by several internal and external factors, including the barometric pressure at the portals, the tunnel slope, and the set-point of the ventilation system [5]. The reliability of computer predictions of this complex system has been evaluated in many studies. Ventila- tion velocity and backlayering distance were validated in [6, 7]. In [6, 8, local field data, e.g., velocity and gas temperature in the vicinity of the fire source, were predicted and were validated against experimental results. On the basis of the results of these and other studies, Colella stated [9] that the CFD method can be used to produce sufficiently accurate results of the flow pattern and the temperature gradient in areas close to a fire. However, as has been was mentioned above, the reliability of the numerical solution and the accuracy of the results have to be checked.

Verification and validation $(\mathrm{V} \& \mathrm{~V})$ procedures are nowadays recognized as the primary method for evaluating the confidence of computer simulations [10]. For verification, computational solutions are compared with highly accurate (analytical or numerical) benchmark solutions, and among themselves. Verification should provide evidence that the mathematical models have been properly implemented, and that the numerical solution is correct with respect to the mathematical model. Due to the high complexity of the problems that are of practical importance, this verification can be conducted only using an approach where the reasoning is based on experience from repeated calculations. A standard example is error estimation based on numerical results for different mesh resolutions. Numerical solutions applied for verification can be mathematical models with little physical importance. The problem that is considered should be relatively simple [10. Nevertheless, it is pointed out in [11] that even the most extensive verification cannot remove all errors. The validation process evaluates the level of agreement between a computer prediction and a physical model, i.e., experimental results. The general principles of $\mathrm{V} \& \mathrm{~V}$ are introduced in 12 .14.

In this paper, the gas temperature resolution and 
the gas flow in regions within the vicinity of the fire source in a tunnel are simulated by Fire Dynamics Simulator v6 (FDS) mathematical code [15]. A simplified model of a tunnel is used in order to verify results from FDS against the results produced by the SmartFire v4.3 mathematical code [16]. The influence of mesh size on the results for the gas temperature in the close vicinity of the fire source is studied in FDS. Finally, the prediction of the gas temperature resolution in tunnel structures with the aid of the FDS code is validated against the results of a fire test in the Valík tunnel in the Czech Republic.

\section{Numerical MODELLing}

During a fire in a tunnel, there are three-dimensional flows which are influenced by buoyancy effects. In addition, the flow velocity and the length scales are large enough for the flow to be generally turbulent. In the fire, a combustion process takes place, and so there are chemical reactions going on, producing soot particles and combustion products at high temperatures [17. Part of the heat is transferred by radiation and part is transferred by convection to the tunnel walls. Models to predict the growth rate of a fire can be formulated, but complete knowledge of the properties of the reacting material is required. CFD models can provide a framework for including all these phenomena in a calculation. The Fire Dynamics Simulator [15] and SmartFire [16] computer programs, which are frequently used representatives of CFD fire modeling, are employed in this study.

Both of these computational codes are based on the CFD method. CFD is a numerical approach to representing fluids that divides a fluid domain into a number of smaller subdomains, resulting in the generation of a mesh (or a grid) of cells (elements or control volumes, represented by $\Delta x, \Delta y, \Delta z$ in Cartesian coordinates). Three-dimensional, time-dependent partial differential equations of mass conservation, momentum and energy transfer and conservation of species are written for each control volume on the basis of the fundamental equations of fluid dynamics, thermodynamics, chemical reactions and mechanics [18]. They are then numerically assembled for the entire fire enclosure to simulate the growth and the behaviour of the fire. Appropriate initial boundary conditions are then applied to find numerical solutions to these equations. The preview of the results obtained using 3D visualization, which provides a better understanding of the physical processes during the fire. is a clear benefit of the numerical method. A disadvantage of CFD models is that they make big demands on hardware and on time.

The Fire Dynamics Simulator, a freely-available numerical code developed by the National Institute of Standards and Technology, is frequently used for simulating fires. It is a numerical solver for simulating the flow and the movement of fluids, including fluids caused by burning. FDS numerically solves a form of the Navier-Stokes equation appropriate for low-speed, thermally-driven flow, with emphasis on the transport of heat and smoke from fires 15 .

SmartFire is a commercial numerical solver developed at the University of Greenwich [16]. The solver is based on the same methodology as was described above. However, it is equipped with many automated tools that FDS does not have, e.g., selection of the solver, the time step, meshing, etc. which are intended to simplify the work of users.

\subsection{MODEL OF A TUNNEL}

In order to keep the problem relatively simple, a part of a model of a single-track railway tunnel is used. The model consists of the simple geometry of a tunnel $50 \mathrm{~m}$ in length and a rectangular cross section with dimensions of $5.0 \times 5.0 \mathrm{~m}$. The computational domain consists of three meshes with a division of $200 \times 20 \times 20$ (denoted as a coarse grid). The fire outbreak with constant power of $1 \mathrm{MW}$ and dimensions of $2.0 \times$ $1.0 \times 0.5 \mathrm{~m}$ is located in the middle of the tunnel length (in FDS code, an obstacle with a surface with a specified heat release rate per unit area HRRPUA = $500 \mathrm{~kW} / \mathrm{m}^{2}$ ). The tunnel is made of an absolutely non-conductive material (in FDS code, an adiabatic surface, with a layer thickness of $0.1 \mathrm{~m}$ ). The tunnel portals opened throughout the cross-sectional area provide a natural gas flow (in FDS code, plane surface type VENT is OPEN). Before activating the burner, the inner tunnel environment is set, the initial gas temperature is $15^{\circ} \mathrm{C}$ (in FDS code, TMPA). There are no flammable materials in the tunnel. The total simulation time is $150 \mathrm{~s}$. The gas temperature and the gas velocity are calculated both in FDS code and in SmartFire code, in the axis of the tunnel cross section at a height of $0.55 \mathrm{~m}$ below the ceiling.. In the FDS, turbulence model of large eddy simulation (LES) with coefficient $C_{\mathrm{s}}$ equal to 0.2 is applied by the Smagorinski formulas. By contrast, SmartFire uses a RANS-based model to solve the turbulence flows. In SmartFire reaction of burning is kept in default settings. In FDS, a mixed-fraction model of propane is used. Heat transfer by radiation is applied by 100 discrete angles in FDS, and by a 24-ray model in Smart Fire.

\subsection{Results}

A graphic visualization from FDS computing code of the flow of hot gases and of the gas velocity on a plane located in the middle of the tunnel width is shown in Figure 1 and Figure 2 Considering the same boundary conditions at both portals of the tunnel and a symmetrically located fire outbreak, the layer of smoke and hot gases travels almost uniformly in both directions. In Figure 1, a border of $80^{\circ} \mathrm{C}$, which is assumed to be critical for escaping persons, is highlighted. The figures show that the thickness of the layer of hot gas below the ceiling does not grow significantly between $30 \mathrm{~s}$ to $100 \mathrm{~s}$ due to the sufficient 

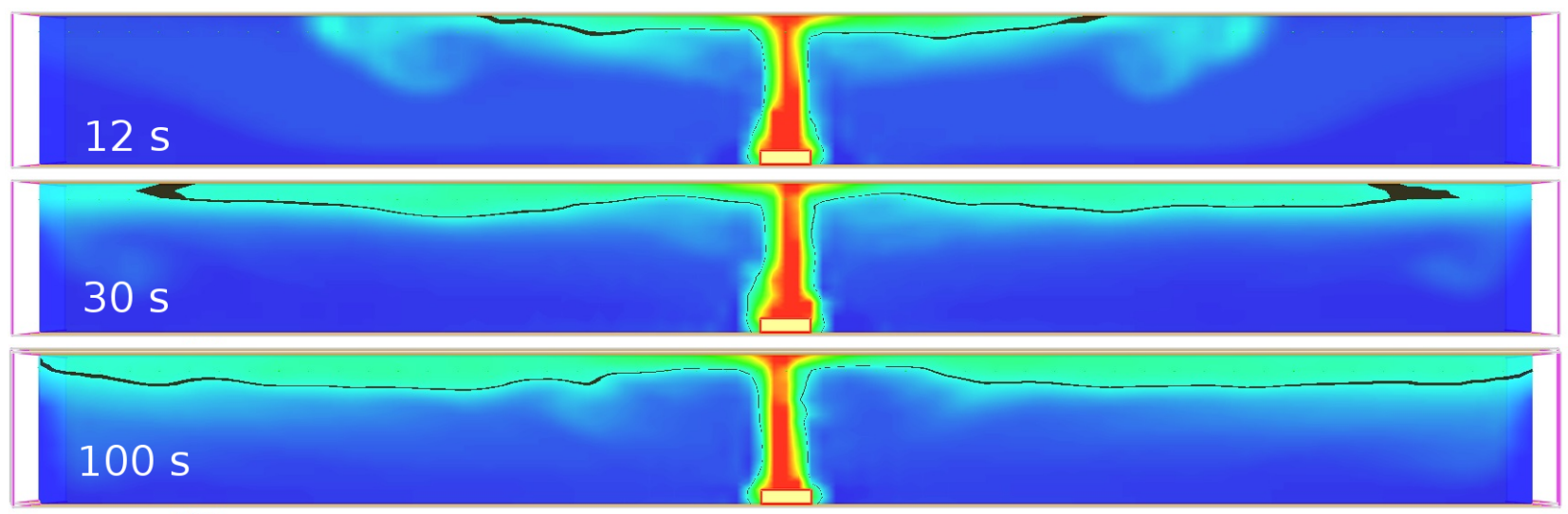

Temperature $\left({ }^{\circ} \mathrm{C}\right)$

$\begin{array}{llllllllll}15 & 40 & 65 & 90 & 115 & 140 & 165 & 190 & 215 & 240\end{array}$

Figure 1. Visualization of the development of hot gases at 12, 30 and $100 \mathrm{s.}$
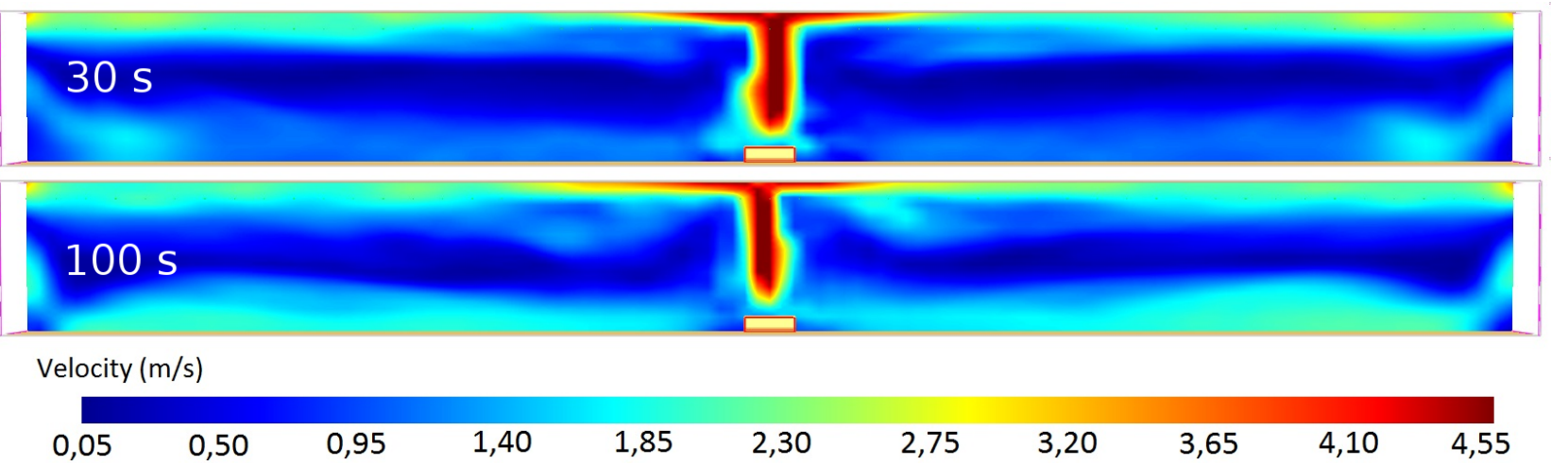

FiguRe 2. Visualization of the gas flow velocity at 30 and $100 \mathrm{~s}$.

supply of cool air in a relatively short tunnel. Gases at a higher temperature gradually move further away from the centre of the burner to the tunnel portals. A careful look at Figure 2 reveals an inflow of fresh air towards the fire outbreak. The gas temperature and the visibility of the gas flow velocity, and also the content of toxic substances in the combustion products and the temperature of the lining structure can be determined from a numerical calculation.

The results for the gas temperature of the FDS and SmartFire computing codes detected by a linear sensor placed in the axis of the tunnel cross section at a height of $0.55 \mathrm{~m}$ below the ceiling at $30 \mathrm{~s}$ and at $100 \mathrm{~s}$ are shown in Figure 3 [19]. As expected, the highest temperature is directly above the burner. With increasing distance from the burner, the temperature decreases. Nevertheless, the observed temperature is unexpectedly low in the region between the burner and the part of the tunnel where one-dimensional flow is dominant (about 5 meters in both directions from the axis of the burner). This may be influenced by the high velocity and the high temperature gradients in this region. These characteristics cannot be captured when a relatively coarse mesh is used.

Outside the area affected by the direct influence of the burner, the gas layer under the ceiling is be- low $100^{\circ} \mathrm{C}$. There is no big difference between the values reached at $30 \mathrm{~s}$ and at $100 \mathrm{~s}$. The temperature decreases with increasing distance from the burner.

\section{VERIFICATION}

In order to verify the model of the development of hot smoke in the railway tunnel, a comparison was made between the gas temperatures generated by the FDS computing code and by the SmartFire computing code. Gas temperatures were detected by a linear sensor placed on the axis of the tunnel cross section at a height of $0.55 \mathrm{~m}$ below the ceiling at $30 \mathrm{~s}$ and at $100 \mathrm{~s}$. From the ratio of the calculated gas temperature values (FDS/SmartFire) along the tunnel length in Figure 4 it can be seen that the maximum difference in the area affected by flames ( 5 meters in both directions from the axis of the burner) is about $20 \%$. In the region of dominant one-dimensional gas flow, further from the axis of the burner, the values differ by up to $10 \%$. According to probability theory and statistical theory, the data can be described by the arithmetic mean, the mean square error and the standard deviation at a time of $30 \mathrm{~s}$ are $(0.96,0.01,0.08)$ and at $100 \mathrm{~s}$ the values are $(0.97,0.01,0.10)$. The Pearson correlation coefficient is equal to 0.978 at $30 \mathrm{~s}$, and at $100 \mathrm{~s}$ it is equal to 0.970 . The results of the statistical 


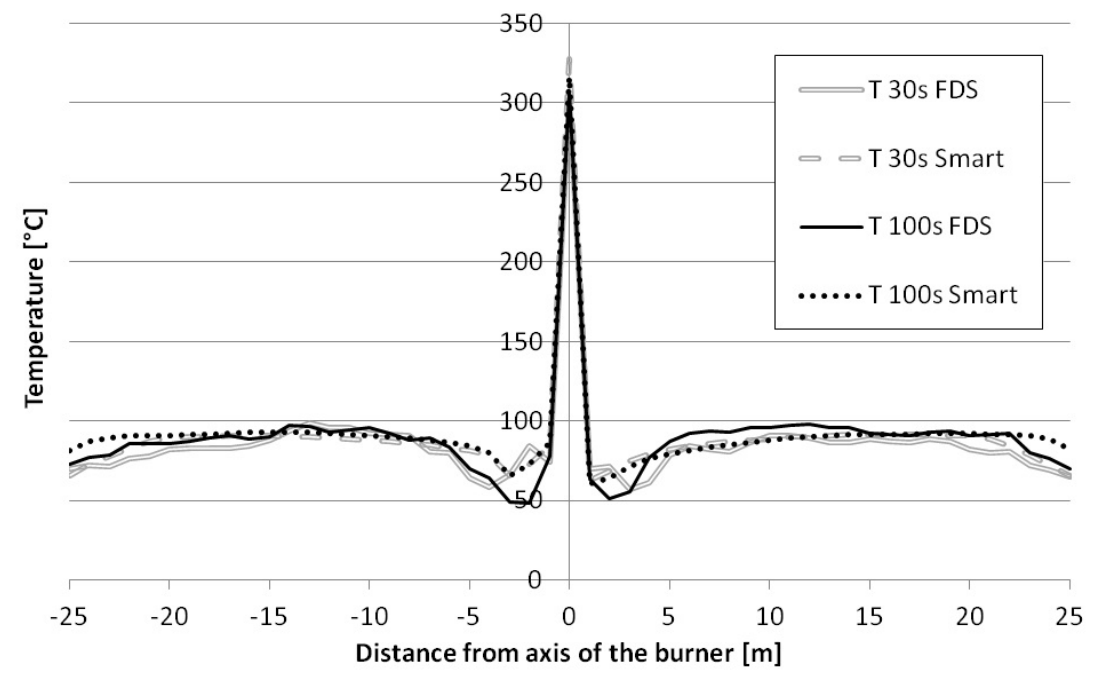

Figure 3. Gas temperature distribution along the tunnel length at $30 \mathrm{~s}$ and at $100 \mathrm{~s}$ (the origin of the $x$ axis lies on the axis of the burner) [19.

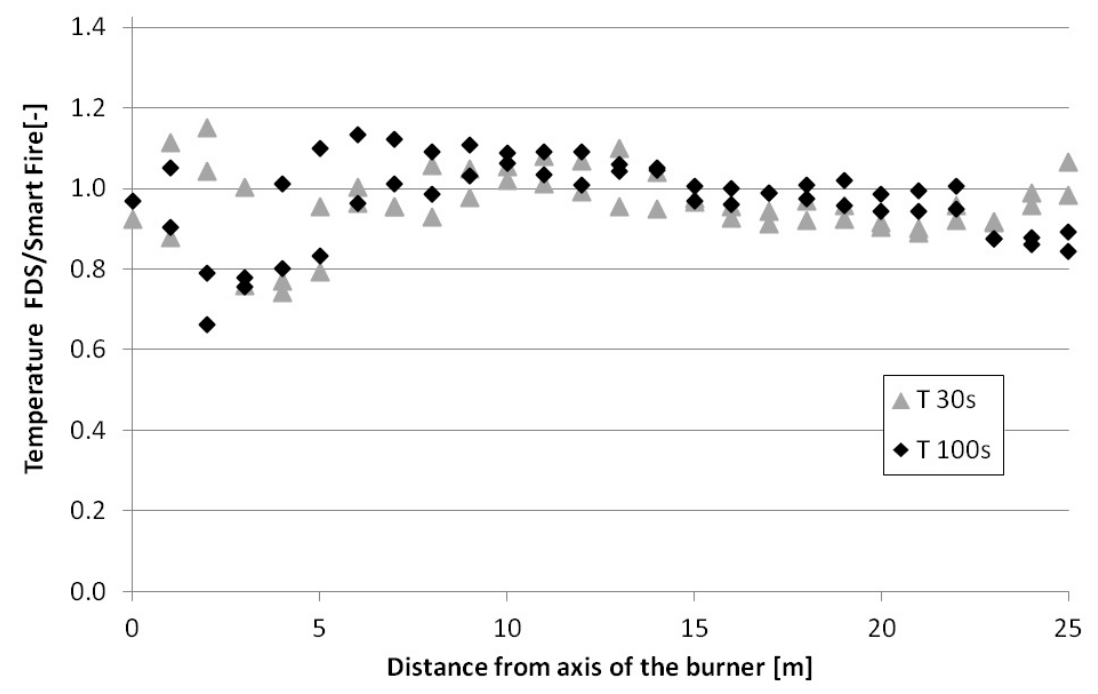

Figure 4. Verification of the gas temperature at $30 \mathrm{~s}$ and at $100 \mathrm{~s}$.

relationships demonstrate that the verification of the numerical model in both softwared has reached good agreement both for FDS software and for SmartFire software.

\subsection{Sensitivity STUDY}

To estimate the error on the basis of different mesh resolutions of a numerical model, calculations of the same model as was described in Section 2.1 are performed using different mesh densities. In this case, a finer division of $400 \times 40 \times 40$ is applied to all meshes. Then the size of a grid cell is $0.125 \mathrm{~m}$. Figure 5 presents gas temperature resolution results at $30 \mathrm{~s}$ and at $100 \mathrm{~s}$. The temperature is calculated in the same position, i.e., $0.55 \mathrm{~m}$ below the tunnel ceiling. Unlike in Figure 3, only one symmetrical part of the tunnel is presented. For the maximum temperature above the burner, $100{ }^{\circ} \mathrm{C}$ higher temperatures are generated by the model with the finer mesh. In the part of the tunnel where one-dimensional flow is dominant, the temperature is more than $100^{\circ} \mathrm{C}$ comparing to the model with the coarse mesh. The biggest influence of the application of the finer mesh can be seen in the region between the burner and the part of the tunnel where one-dimensional flow is dominant. The drop in temperature described above has disappeared, and the results look more reliable.

Figure 6 illustrates the influence of grid size on gas temperature in the regions described above. In the region with dominant one-dimensional flow, the temperature rise of the model with the finer mesh is about $20 \%$. However, the temperatures in the most affected field differ by as much as $100 \%$.

\section{VAlidation}

Data measured during the fire test in the Valík road tunnel carried out in 2006 [20, 21] were used to validate the numerical simulation in FDS software. 


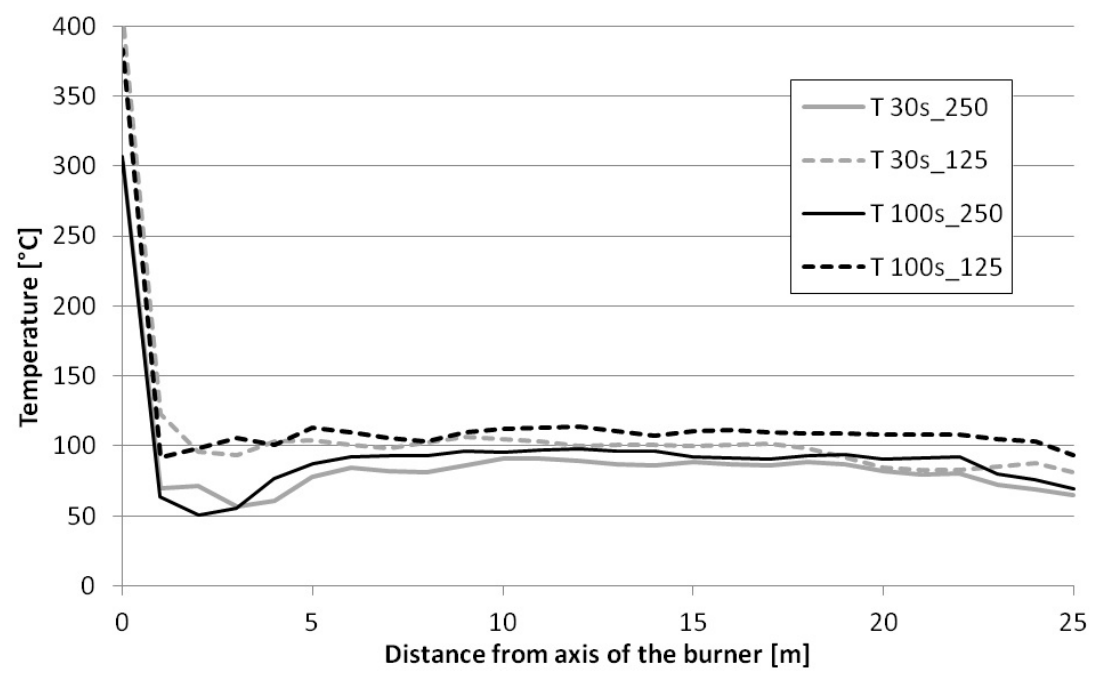

FIGURE 5. Influence of grid size on gas temperature resolution in the FDS model.

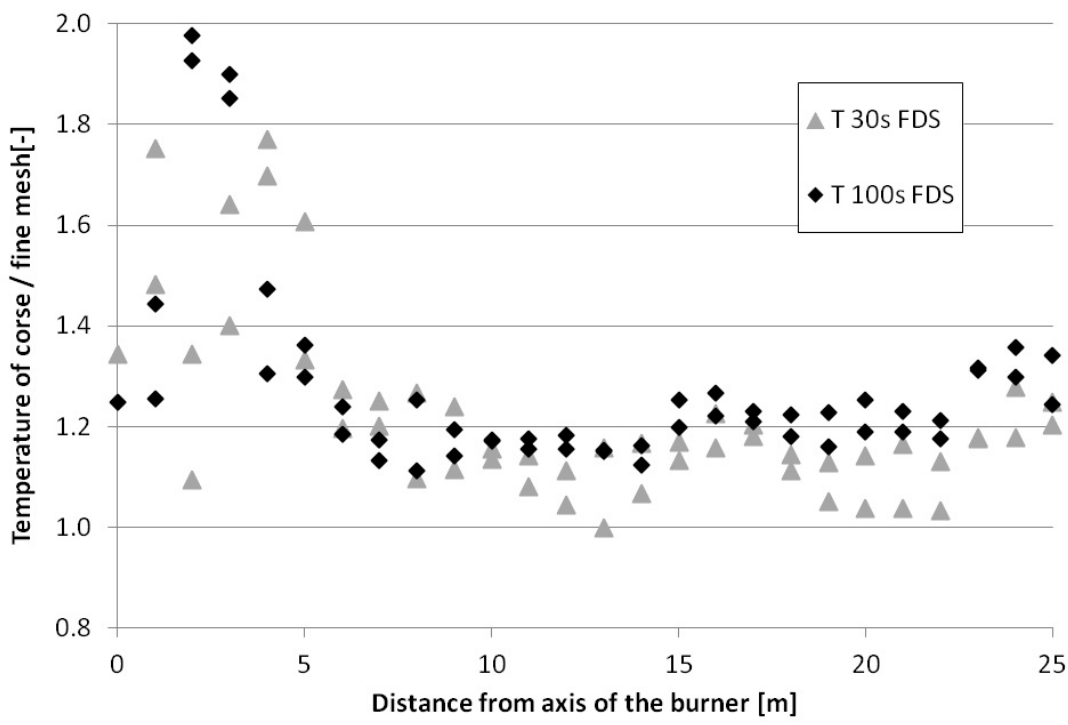

FigURE 6. Verification of the influence of grid size on gas temperature resolution at $30 \mathrm{~s}$ and at $100 \mathrm{~s}$.

\subsection{FiRE TEST}

The Valík road tunnel is situated on the D5 highway close to Pilsen, in the western part of the Czech Republic. The tunnel consists of two $390 \mathrm{~m}$-long tubes. The width of the traffic lane between the curbs is $11.5 \mathrm{~m}$ (the total clearance width is $14 \mathrm{~m}$ ) and the top of the arch above the vertical alignment is $8.16 \mathrm{~m}$ (the traffic clearance height is $4.8 \mathrm{~m}$ ). The cross-section of the twin-tube tunnel is illustrated in Figure 7 [22]. The transverse slope of the traffic lane is $2.5 \%$, the vertical alignment is a $4 \%$ longitudinal slope, and the radius of the direction arc is $2280 \mathrm{~m} 21$.

Two fire tests were carried out in the Valík tunnel to simulate a fire in a passenger car. $170 \mathrm{l}$ of petrol in an open pool of $4 \mathrm{~m}^{2}$ were used to provide a heat release rate of $5 \mathrm{MW}$. The pool was placed on a 1-metre-high support base in the axis of the tunnel tube. Various boundary conditions were applied during the fire tests. The gas flow during the first test was supported by forced ventilation. The second test was initiated with normal conditions, and forced ventilation was started subsequently. The characteristic gas flow velocity value was $2.5 \mathrm{~m} / \mathrm{s}$. During both fire tests, a number of fire characteristics were measured at several height levels and in several vertical sections - hot smoke temperature, surface temperature of the tunnel structure, velocity of the gas flow, and height of the smoke layer [21].

\subsection{FDS MODELLING}

In the validation process, the two models were prepared similarly, as was introduced in 20] - a smallscale model that simulates only a limited part of the tunnel, and a model with the real dimensions. The cross-section of both models was simplified to a rectangular shape $11.5 \mathrm{~m}$ in width and $8.0 \mathrm{~m}$ in height. The lengths of the models differed - the small-scale model was $25 \mathrm{~m}$ in length, while the second model $300 \mathrm{~m}$ in length corresponds with the real dimensions of the tunnel. In both cases, the computa- 


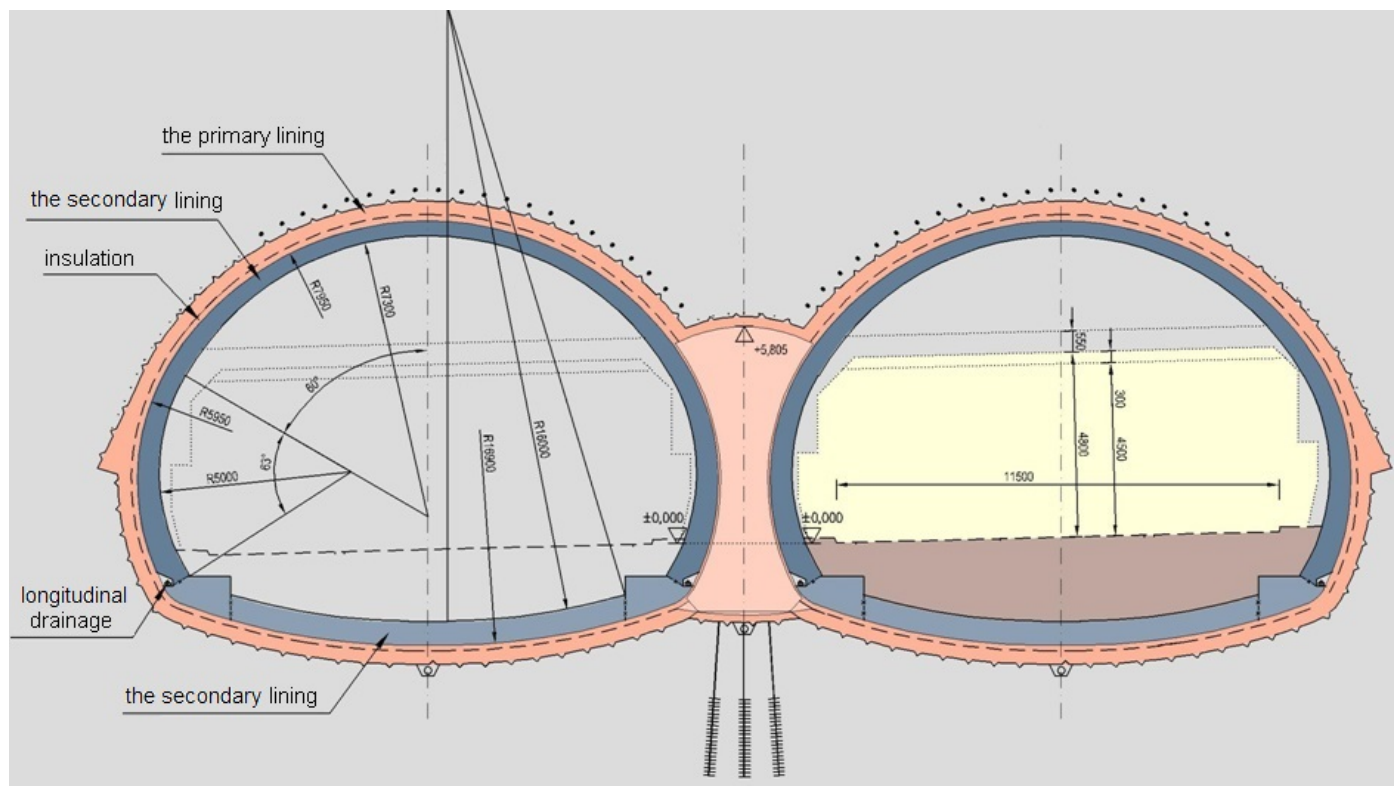

Figure 7. Cross-section of the Valík tunnel [22].
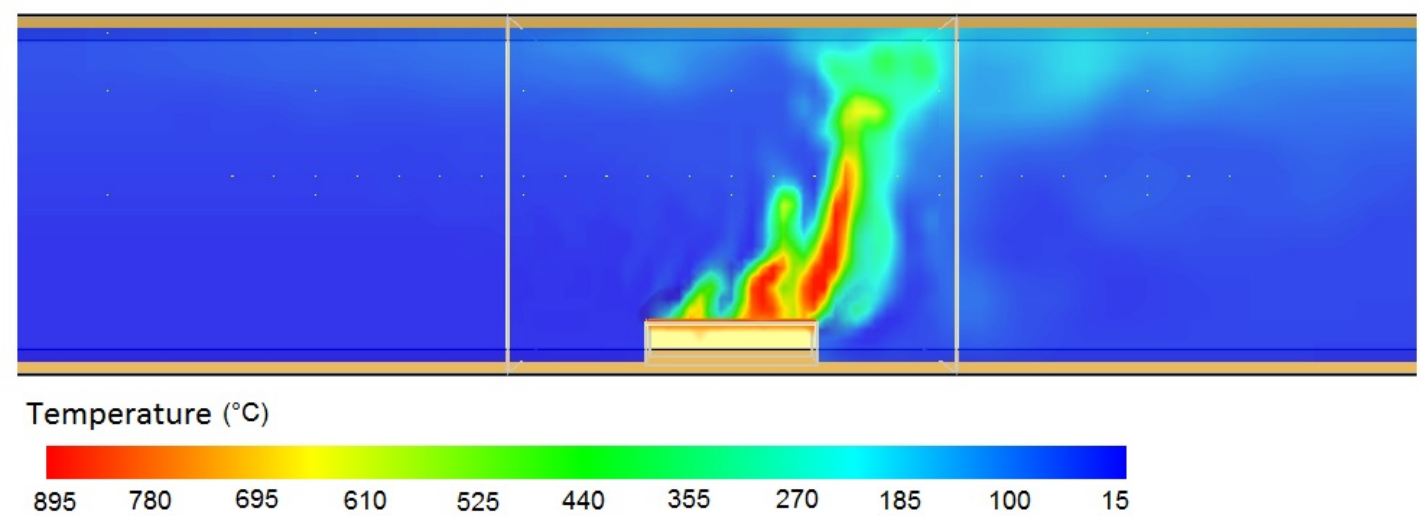

Figure 8. Gas temperature resolution in a model of the fire test in the Valík tunnel, with an initial gas flow velocity of $2 \mathrm{~m} / \mathrm{s}$.

tional domain consisted of three meshes with a finer mesh in the region of the fire source. Mesh sizes of $0.25 \times 0.25 \times 0.25 \mathrm{~m}$ (denoted as the coarse grid) and $0.125 \times 0.125 \times 0.125 \mathrm{~m}$ (denoted as the fine grid) were applied in the small-scale model. The model with the real dimensions was solved with three different combinations of grid sizes: (a) $0.50 \times 0.50 \times 0.50 \mathrm{~m}$ (coarse grid) and $0.25 \times 0.25 \times 0.25 \mathrm{~m}$ (fine grid), $(\mathrm{b})$ $0.50 \times 0.50 \times 0.50 \mathrm{~m}$ (coarse grid) and $0.125 \times 0.125 \times$ $0.125 \mathrm{~m}$ (fine grid), and (c) $0.25 \times 0.25 \times 0.25 \mathrm{~m}$ (coarse grid) and $0.125 \times 0.125 \times 0.125 \mathrm{~m}$ (fine grid). The fire outbreak with constant power of $5 \mathrm{MW}$ and dimensions of $2.0 \times 2.0 \mathrm{~m}$ was located in the middle of the tunnel length (in FDS code, an obstacle $1 \mathrm{~m}$ in height with the upper surface of the specified heat release rate per unit area $\mathrm{HRRPUA}=1250 \mathrm{~kW} / \mathrm{m}^{2}$ ). The burning reaction was set to a mixed-fraction model of polyurethane (material GM27 in [23]). The tunnel linings were made of a layer of concrete $0.1 \mathrm{~m}$ in thickness. The material characteristics are introduced in Table 1. The tunnel portals are opened. Before

\begin{tabular}{lc}
\hline Specific heat & $1.2 \mathrm{~kJ} / \mathrm{kg} \mathrm{K}$ \\
Conductivity & $1.3 \mathrm{~W} / \mathrm{mK}$ \\
Density & $2200 \mathrm{~kg} / \mathrm{m}^{3}$ \\
Emissivity & 1.0 \\
\hline
\end{tabular}

TABLE 1. Specific characteristics used in the FDS model.

the burner was activated, the initial gas temperature was set to $15^{\circ} \mathrm{C}$ and the humidity was set to $60 \%$. A different initial gas flow velocity value $(0-3 \mathrm{~m} / \mathrm{s})$ was considered in each model. The turbulence model and the heat transfer by radiation were kept the same as described in Section 2.1.

Figure 8 shows a detail of a model with dimensions of $8 \times 11 \mathrm{~m}$ and $300 \mathrm{~m}$ in length, in which resolutions of the gas temperature are visible. A $5 \mathrm{MW}$ source of fire (a burner) is situated on a support base $1 \mathrm{~m}$ in height in the axis of the tunnel. White lines show the borders of three computational meshes applied to the model. 


\begin{tabular}{lll}
\hline \multicolumn{1}{c}{ Model (description) } & $T_{\max }$ & Location of maximal temperature \\
\hline Small-scale $(0 \mathrm{~m} / \mathrm{s}$, mesh $0.25 \mathrm{~m}+0.125 \mathrm{~m})$ & $140{ }^{\circ} \mathrm{C}$ & section in $10 \mathrm{~m}$, height level of $7.9 \mathrm{~m}$ \\
\hline Real $(2 \mathrm{~m} / \mathrm{s}$, mesh $0.5 \mathrm{~m}+0.25 \mathrm{~m})$ & $200^{\circ} \mathrm{C}$ & section in $5 \mathrm{~m}$, height level of $6.5 \mathrm{~m}$ \\
\hline Real $(3 \mathrm{~m} / \mathrm{s}$, mesh $0.5 \mathrm{~m}+0.25 \mathrm{~m})$ & $190^{\circ} \mathrm{C}$ & section in $5 \mathrm{~m}$, height level of $6.5 \mathrm{~m}$ \\
\hline Real $(0 \mathrm{~m} / \mathrm{s}$, mesh $0.5 \mathrm{~m}+0.125 \mathrm{~m})$ & $160^{\circ} \mathrm{C}$ & section in 5 and $10 \mathrm{~m}$, height level of $6.5 \mathrm{~m}$ \\
\hline
\end{tabular}

TABLE 2. Results of numerical modelling.

\subsection{COMPARison OF RESUlts}

The numerical model is validated with experimental results with the aid of the gas temperature, which was calculated at three height levels $(4.0,6.5$ and $7.9 \mathrm{~m})$ and in several vertical sections from the source of the fire $(0,5,10$ and $15 \mathrm{~m})$. The results of both models, the small-scale model and the model with real dimensions, are presented in Table 22 The description of the models includes the initial gas flow velocity and the grid size (coarse mesh + fine mesh). The last column indicates the location of the maximal temperature calculated in the model. The temperature introduced in the table does not include the short term diversions caused by high fluctuation of the hot gases. According to [9, the maximal gas temperature measured during the first fire test with running forced ventilation was $195.4^{\circ} \mathrm{C}$. On the basis of the results introduced in Table 2 and a comparison with the results introduced in [20], it can be stated that the model with real dimensions corresponds to the measured values within acceptable limits. Thus mathematical modelling in FDS may be used for predicting the gas temperature environment in tunnels with the consequent fire and smoke characteristics, which are useful for fire safety engineering.

\section{Conclusions}

Correctly applied CFD models can reproduce the qualitative behaviour of a fire in a tunnel. It is necessary to use a verification and validation process to find out the degree to which qualitative agreement is achieved. The verification study presented in this paper shows a relatively simple model of a single track railway tunnel solved in two independent codes - in FDS and in SmartFire. The results of the statistical relationships demonstrate that the verification of the numerical model reached good agreement (the Pearson correlation coefficient was equal to 0.97 ). In order to estimate the error on the basis of different mesh resolutions of the numerical model, calculations of the same model are performed using different mesh densities. The sensitivity study that was undertaken shows that the application of a relatively coarse mesh in regions influenced by high velocity and high temperature gradients does not lead to reliable results. It is therefore recommended to apply a finer mesh in the region adjacent to the burner. However, in the region where one-dimensional flow dominates, a coarser mesh may be used to reduce the calculation time. For a tunnel several kilometres in length, the computational domain can be large, and the resulting computing time can be very long. Because of the benefits of the dominant one-dimensional (1D) gas flow in tunnels, a multi-scale modelling method was introduced in 24. In this method, the CFD solution is used only in the region within the vicinity of the fire source, while far-field regions are simulated using a 1D model. This hybrid model leads to a significant reduction in time.

In the validation process, a simplified model of a tunnel tube is compared with the results of the fire test in the Valík road tunnel. On the basis of the achieved correlation of the model with real dimensions, it can be stated that mathematical modelling in FDS and in SmartFire, which has been verified in this study, can be used to predict the gas temperature environment in tunnels. However, the model presented here corresponds to a road tunnel, and the fire dynamics in a railway tunnel is assumed to be practically identical.

However, there are some differences between road tunnels and railway tunnels. Firstly, in the event of a fire in a railway tunnel there is a potential for a larger number of casualties and for greater loss of transported material than in a road tunnel. This is because a single train can transport great numbers people and/or large quantities of material. Secondly, the technical equipment of railway tunnels is not adequate. $82 \%$ of railway tunnels built before 1945 were in recent years still practically without any safety facilities. However, since 2002, in direct response to Commission regulations of the technical specification for interoperability related safety in railway tunnels of the rail system of the European Union, new Czech standard [25] based on European Commission regulations has been applied. In the Czech Republic, the technical equipment has been upgraded in recent years. Generally, the problem of fire safety in tunnels increases with their length. In the case of railway tunnels, the fire dynamics is influenced by high longitudinal flow due to natural ventilation and also supported by moving trains (known as the "piston effect"). This makes the fluid dynamics in the event of a fire in a railway tunnel very complicated. However, the degree to which qualitative agreement between mathematical and physical model is achieved varies according to the modeller and the situation: this is a topic that requires further study. 


\section{ACKNOWLEDGEMENTS}

Work on the research presented in this paper has been supported within the framework of Czech Science Foundation (GA CR) project no. 16-18448S.

\section{REFERENCES}

[1] McGrattan, K. Fire modelling: Where are we? Where are we going? Fire Safety Science - Proceedings of the 8th International Symposium 2005, 8, pp. 53-68.

[2] Jahn, W., Rein, G. and Torero, J.L. A posteriori modelling of the growth phase of Dalmarnock fire test one, Building and Environment, Vol. 46, Issue 5, 2011, pp. 1065-1073. DOI:10.1016/j.buildenv.2010.11.001

[3] Gillie, M., Wald, F., Horova, K. Design fires for structural engineering, In: Urban Habitat Constructions under Catastrophic Events, pp. 7 - 17, 2010. ISBN 978-0-415-60686-8.

[4] Rein, G., Empis, C.A., Carvel, R.O. (ed), The Dalmarnock fire tests: Experiments and Modelling, Chapter 10: A Priori Modelling of Fire Test One, University of Edinburgh, 2007, ISBN 978-0955749704.

[5] Beard, A. and Carvel, R. (ed), Handbook of Tunnel Fire Safety, 2nd edition, ICE Publishing, 2005, ISBN 978-0-7277-4153-0.

[6] Vauquelin, O. and Wu, Y. Influence of tunnel width on longitudinal smoke control, Fire Safety Journal, Vol. 42, Issue 6, 2006, pp. 420-426. DOI:10.1016/j.firesaf.2006.02.007

[7] Van Maele, K., and Merci, B. Application of RANS and LES field simulations to predict the critical ventilation velocity in longitudinally ventilated horizontal tunnels, Fire Safety Journal, Vol. 43, Issue 8, 2008, pp. 598-609. DOI:10.1016/j.firesaf.2008.02.002

[8] Vega, M.G., Arguelles Diaz, K.M., Oro, J.M.F., Ballesteros, T.R., Morros, C.S. Numerical 3D simulation of a longitudinal ventilation system: Memorial Tunnel case, In Tunelling and Underground Space Technology, Vol. 23, Issue 5, 2008, pp. 539-551. DOI:10.1016/j.tust.2007.10.001

[9] Collela, F., Verda, V., Borchiellini, R., Rein, G. One-dimensional and multi-scale modelling of tunnel ventilation and fires, Chapter 17 in Handbook of Tunnel Fire Safety, 2nd edition, ICE Publishing, London, UK, pp. 365-390, doi: 10.1680/htfs.41530.365

[10] Kwasniewski, L., Bojanowski, C. Principles of Verification and Validation. Proceedings of International Conference Applications of Structural Fire Engineering, 19-20 April, 2013, Prague, Czech Republic, 2013, p. $13-22$.

[11] ASME, 2006. Guide for Verification and Validation in Computational Solid Mechanics, The American Society of Mechanical Engineers, ISBN 079183042X.
[12] ISO FDIS 16730, Fire safety engineering - Assessment, verification and validation of calculation methods, 2008.

[13] Wald, F., et al. Benchmark studies, Experimental validation of numerical models in fire engineering. CTU Publishing House, Czech Technical University in Prague, 2014.

[14] Wald, F., et al.: Benchmark studies, Verification of numerical models in fire engineering. CTU Publishing House, Czech Technical University in Prague, 2014.

[15] McGrattan, K. et al. Fire Dynamics Simulator (Version 6.4), Technical Reference Guide. NIST Special Publication 1019-6, p. 86, April 2016, U.S. Government Printing Office, Washington, DOI:10.6028/NIST.SP.1019

[16] Ewer, J. et al. Smart Fire (Version 4.3) - User guide and technical manual. Smartfire tutorials, September 2013.

[17] Rhodes, N. CFD modelling of tunnel fires, Chapter 15 in Handbook of Tunnel Fire Safety, 2nd edition, ICE Publishing, London, UK, p. 329-346, doi: $10.1680 /$ htfs. 41530.329

[18] Silva, J.C. and Landesmann, A. Performance-based analysis of steel-concrete composite floor exposed to fire, Journal of Constructional Steel Research, Vol. 83, pp. 117-126, DOI:10.1016/j.jcsr.2013.01.009

[19] Horová, K., et al. Verification of numerical model of fire and smoke development in railway tunnel. Proceedings of the International Conference in Dubrovnik, 15-16 October 2015, Applications of Structural Fire Engineering, DOI:10.14311/asfe.2015.058

[20] Pokorný, J., Hora, J.: Požární zkoušky v tunelu Valík, Praktická aplikace některých poznatků. Sborník přednášek konference Červený kohout, 2007.

[21] Dvořák, O., et al.: Závěrečná zpráva výzkumného projektu „Vývoj a validace požárních modelů pro stanovení vývinu/šíření tepla a kouře, toxických plynů, tlakových vln pro simulaci/interpretaci scénářù požárů/výbuchů a jejich ničivých účinků. Praha, 2008.

[22] Svoboda, J.: Stavba dvoutubusového tunelu Valík, součást obchvatu Plzně na dálnici D5. Stavebnictví, 067/07, http://www.casopisstavebnictvi.cz/stavbadvoutubusoveho-tunelu-valik-soucast-obchvatuplzne-na-dalnici-d-5_N229. [2016-12-01].

[23] DiNenno, P. J. (ed), SFPE Handbook of fire protection engineering. Third edition. National Fire Protection Association, Inc., Quincy, Massachusetts 02269, 2002. ISBN: 087765-451-4.

[24] Colella, F., Rein, G., Torero, J.L., Borchiellini, T. A novel multiscale methodology for simulating tunnel ventilation flows during fires, Fire Technology, 47, 221-253, 2011, DOI:10.1007/s10694-010-0144-2

[25] ČSN 737508 Železniční tunely, Český normalizační institut, 61782, 2002. 